\title{
Hoeder van de raad of functie zonder inhoud?
}

\author{
Een beschouwing op het vicevoorzitterschap van de \\ gemeenteraad
}

Niels Karsten \& Sabine van Zuydam

\begin{abstract}
Ten tijde van de dualisering werd de waarnemend gemeenteraadsvoorzitter ex artikel 77 lid 1 Gemeentewet wel gezien als 'hoeder van de gemeenteraad', die een bijzondere verantwoordelijkheid draagt voor het functioneren van de raad als geheel en hem een gezicht kan geven tegenover het college. Die rol heeft deze 'vicevoorzitter' echter nooit gekregen. Recent is die optie opnieuw geopperd, met als doel de samenwerking binnen de gemeenteraad te bevorderen en de veranderende rol van de gemeenteraad te faciliteren. In dit artikel laten de auteurs zien dat de rol van de vicevoorzitter in de praktijk echter beperkt is, hoewel er wel belang aan wordt gehecht en een meerderheid van de gemeenteraden gebruikmaakt van de bevoegdheid een eigen vicevoorzitter aan te wijzen. Vooralsnog lijkt Nederland op dit punt niet geneigd te leren van Vlaanderen, waar de raad inmiddels een eigen voorzitter aanwijst. Dat heeft onder andere te maken met verschillen tussen de twee burgemeestersfuncties. Tegelijk is zeker niet uit te sluiten dat ook in Nederland in de toekomst, als gevolg van ontwikkelingen in het burgemeestersambt, meer aandacht komt voor het vraagstuk van het (vice)voorzitterschap van de gemeenteraad.
\end{abstract}

\section{Inleiding}

Artikel 77 lid 1 Gemeentewet ${ }^{1}$ bepaalt dat de gemeenteraad de bevoegdheid heeft om uit zijn midden een waarnemend raadsvoorzitter aan te wijzen. Doet de gemeenteraad dit niet, dan wordt het voorzitterschap van de gemeenteraad bij verhindering of ontstentenis van de burgemeester waargenomen door het langstzittende lid van de raad. Deze 'vicevoorzitter' zit bijvoorbeeld de gemeenteraad voor als de burgemeester afwezig is, of vervangt hem of haar in zo'n geval bij een werkbezoek. Als onderdeel van de dualisering werd hij wel gezien als de 'hoeder van de gemeenteraad', die de raad in het samenspel met het college goed voor het voetlicht zou kunnen brengen (Stuurgroep Evaluatie Dualisering Gemeentebestuur, 2004). Dat zou onder andere de samenwerking in de raad kunnen bevorderen en de controlerende taak van de gemeenteraad kunnen versterken.

1 Bij verhindering of ontstentenis van de burgemeester wordt zijn ambt waargenomen door een door het college aan te wijzen wethouder. Het voorzitterschap van de raad wordt in dat geval waargenomen door het langstzittende lid van de raad. Indien meer leden van de raad even lang zitting hebben, vindt de waarneming plaats door het oudste lid in jaren van hen. De raad kan een ander lid van de raad met de waarneming belasten. 
Zo'n vijftien jaar later stelt Van Ostaaijen (2016) echter vast dat de functie van de vicevoorzitter binnen het lokaal bestuur nog maar beperkt ontwikkeld is. Aanleiding om over zijn rol en verantwoordelijkheden na te denken is er echter wel degelijk. Wij zien daarvoor ten minste vier redenen: (a) de veranderende rol van de gemeenteraad, (b) de veranderende samenstelling van gemeenteraden, (c) de veranderende rol van de burgemeester en (d) de kans om te leren van de ervaringen met gemeenteraadsvoorzitters in Vlaanderen.

\section{- Ad a. Veranderende rol van de gemeenteraad}

In de eerste plaats verandert de rol van de gemeenteraad fundamenteel door de opkomst van een participatiesamenleving en als gevolg van decentralisatie en regionalisering (Fraanje, 2015; Gilsing e.a., 2015; Kruiter \& De Lange, 2014). Dat transformatieproces vraagt om een raad die actief nadenkt over zijn rol in het lokaal bestuur en in de samenleving en die in staat is innovatieve manieren van werken te ontwikkelen. Er zou zelfs een 'grondige verandering van de gegroeide cultuur' nodig zijn, en daarvoor is 'onderlinge samenwerking in de raad' nodig (Raad van State, 2017; Rob, 2016a: 27). De gemeenteraad wordt echter gekenmerkt door verdeeldheid. Aan die verdeeldheid ontleent de gemeenteraad, als politiek orgaan, deels zijn bestaansrecht. Tegelijk maakt deze het lastiger om het goed functioneren van de gemeenteraad te bewaken en daarin te vernieuwen. De vicevoorzitter zou daarin een begeleidende rol kunnen spelen, oppert Van Ostaaijen (2016).

\section{- Ad b. Veranderende samenstelling van gemeenteraden}

In de tweede plaats hebben gemeenteraden te maken met een toenemend aantal fracties en een toenemend aantal partijen dat nodig is voor lokale meerderheden (Krouwel \& Geurkink, 2016; Lunsing \& Herweijer, 2016). Die fragmentatie kan in democratische zin positief uitwerken omdat daarmee de verscheidenheid aan opvattingen die in de lokale samenleving bestaat goed in de raad is vertegenwoordigd, maar verschillende auteurs maken zich zorgen over het vermogen van Nederlandse gemeenteraadsleden om tot constructieve samenwerking te komen (Raad van State, 2017; Rob, 2016a). Zo bestaat het risico dat politieke polarisatie en spanningen toenemen, wat het voor een raad nog lastiger kan maken om zich als één geheel op te stellen en de benodigde samenwerking tussen fracties te bewerkstelligen (Schulz \& Frissen, 2017). 'Het gebeurt slechts in uitzonderlijke gevallen dat de gemeenteraad gezamenlijk en eensgezind een vuist maakt', zo stelt Van Ostaaijen (2016: 9) vast. Hij oppert daarom de mogelijkheid om de vicevoorzitter een bijzondere verantwoordelijkheid te geven voor het functioneren van de raad als geheel. In diezelfde lijn riep Peters (2017) op tot meer eigenstandig leiderschap vanuit de raad. Een raad die leiderschap toont, is beter in staat de controlerende taak ten opzichte van het college handen en voeten te geven, de verbinding met de samenleving te leggen en zich niet te veel af te laten leiden door het college, zo stelt zij. 
Burgemeesters hebben, als voorzitter, een rol in het begeleiden van de gemeenteraad in deze rollen, maar zij voelen meestal een grotere verantwoordelijkheid voor het functioneren van het college en stellen zich veelal terughoudend op in hun relatie met de gemeenteraad (Van Ostaaijen, 2016). Zeker met vraagstukken als fragmentatie of politisering in de raad houden burgemeesters zich veelal niet actief bezig, omdat dat vooral de verantwoordelijkheid van de raad zelf zou zijn (Karsten e.a., 2014). Ook griffiers hebben een rol in het in goede banen leiden van de fragmentatie van de gemeenteraad, maar de middelen en mogelijkheden van de griffie zijn beperkt en haar inzet in dit kader zorgt al voor een extra belasting van griffiers (Krouwel \& Geurkink, 2016). Nauwere samenwerking met en ondersteuning vanuit de gemeenteraad in de persoon van de vicevoorzitter kan mogelijk bijdragen aan het accommoderen van fragmentatie en het voorkomen van de praktische en politieke problemen die ermee gepaard kunnen gaan.

\section{- Ad c. Veranderende rol van de burgemeester}

In de derde plaats is het ambt van de voorzitter van de gemeenteraad, de burgemeester, de afgelopen jaren zo fundamenteel veranderd, dat ook dat aandacht vraagt voor de rolverdeling tussen burgemeester en vicevoorzitter. Van de gestage uitbreiding van de openbare orde en veiligheid (OVV)-portefeuille van de burgemeester die in de afgelopen jaren heeft plaatsgevonden, gaat een politiserende werking uit, vooral vanwege de politiek-maatschappelijk gevoelige aard van verschillende bevoegdheden. Het ambt van burgemeesters wordt daarmee politieker (Elzinga, 2013; Mein, 2010). Dat kan op gespannen voet staan met hun rol als onpartijdig waker en verbinder. Bovendien zijn de institutionele verhoudingen tussen burgemeester en gemeenteraad inmiddels zodanig veranderd dat de burgemeester voor zijn benoeming, aanblijven en herbenoeming sterk politiek afhankelijk is geworden van de gemeenteraad. Die ontwikkelingen brengen ons dicht bij de aloude discussie over de vraag of de dubbelfunctie van de burgemeester als voorzitter van college én raad wel zo'n gelukkige is (Rob, 2016b; Stuurgroep Evaluatie Dualisering Gemeentebestuur, 2004). Tegenstanders daarvan wijzen er veelal op dat deze 'spagaat' modelmatig niet past in een dualistisch stelsel en de burgemeester ook in de praktijk in de problemen kan brengen (zie Korsten \& Aardema, 2006). Voorstanders van het gecombineerde voorzitterschap zien in de praktijk niet zoveel problemen en wijzen erop dat burgemeesters in deze positie juist een belangrijke verbinding tussen raad en college kunnen leggen (zie Karsten e.a., 2014). We beogen zeker niet dat debat hier te beslechten, maar de ontwikkelingen in en rond het burgemeestersambt maken wel dat de rolverdeling tussen burgemeester en vicevoorzitter een actueel en relevant onderwerp van gesprek is (zie ook Stuurgroep Evaluatie Dualisering Gemeentebestuur, 2004; Van Ostaaijen, 2016). In de praktijk zien we in voorliggend onderzoek namelijk gevallen waar voor dat gesprek geen ruimte is en gevallen waarin ad hoc oplossingen worden gezocht op het moment dat er al politieke spanningen rondom het voorzitterschap van de gemeenteraad zijn ontstaan. 


\section{- Ad d. Leren van Vlaanderen}

Ook een blik over de grens geeft aanleiding om over het samenspel tussen burgemeester en vicevoorzitter na te denken. In 2007 kregen Vlaamse gemeenteraden de mogelijkheid om een andere voorzitter dan de burgemeester aan te wijzen. Dat kan een raadslid zijn, maar ook een schepen. Het doel van deze maatregel was de positie van de gemeenteraad ten opzichte van het college te versterken (Buylen e.a., 2014; Suykens, 2010; Vlaamse Regering, 2005). Ook de ruimte die de maatregel burgemeesters biedt om te focussen op het verdedigen van hun beleid, terwijl ze het leiden van de vergadering overlaten aan een aparte voorzitter, wordt als argument aangedragen (Karsten e.a., 2017). Na de gemeenteraadsverkiezingen van 2006 opteerde nog $68 \%$ van de Vlaamse gemeenten voor het traditionele model met de burgemeester als voorzitter van de gemeenteraad, maar anno 2017 had al $71 \%$ van de gemeenteraden bij onze zuiderburen een eigen voorzitter (Karsten e.a., 2017). Dat is vrijwel altijd een raadslid, en in een enkel geval een schepen. Recentere cijfers ontbreken.

Natuurlijk spreken we hier over een heel ander, monistisch bestuursmodel. Toch biedt een vergelijking met Vlaanderen, rekening houdend met de institutionele en culturele verschillen, goede mogelijkheden om van de ervaringen te leren, zo leert de literatuur over policy transfer (Wolman \& Page, 2002). Er zijn namelijk ook veel overeenkomsten in het functioneren van Nederlandse en Vlaamse gemeenteraden (Van Ostaaijen \& Thijssen, 2017).

\section{Doel en methoden}

Aanleiding om na te denken over de vraag wat het vicevoorzitterschap behelst, is er dus voldoende. Tegelijk is er vrijwel geen empirische kennis over beschikbaar. In dit artikel gaan we daarom in op verschillende aspecten van die vraag. Doel is te beschrijven wat de rol van de vicevoorzitter in de praktijk inhoudt. We analyseren hoe in Nederland wordt aangekeken tegen de rol van de vicevoorzitter en kijken daarbij, ter vergelijking, enkele malen voorzichtig over de NederlandsVlaamse grens.

Voor dit onderzoek is in juni 2017 een digitale enquête verspreid onder alle Nederlandse gemeenteraadsleden en griffiers (voor meer informatie, zie Karsten \& Van Zuydam, 2017). De enquête is uiteindelijk door 1727 raadsleden (19,8\%) ingevuld, evenals door 245 griffiers (64,0\%). Wat betreft partijpolitieke kleur en vertegenwoordiging van een coalitie- dan wel oppositiepartij zijn de raadsleden die de enquête hebben ingevuld representatief voor alle raadsleden in Nederland. Als het gaat om gemeentegrootte is er een kleine vertekening in de respons: raadsleden uit gemeenten kleiner dan 20.000 inwoners zijn enigszins ondervertegenwoordigd, terwijl raadsleden uit gemeenten van 20.000 tot 50.000 inwoners en raadsleden uit gemeenten groter dan 100.000 inwoners enigszins oververtegenwoordigd zijn. Daarbij zijn er relatief veel raadsleden vicevoorzitter van de gemeenteraad (255 van de 1727 raadsleden die de enquête hebben ingevuld). Daar waar dit impact heeft op de resultaten is dat in de tekst aangegeven. Voor de 
deelnemende griffiers geldt dat zij wat betreft gemeentegrootte representatief zijn voor alle griffiers in Nederland.

Naast de enquête hebben we een tweetal focusgroepgesprekken gevoerd met vicevoorzitters en griffiers. Met hen hebben we gesproken over de eerste resultaten van de enquête en hebben we onze voorlopige conclusies en aanbevelingen gespiegeld aan hun ervaringen. Voor informatie over de Vlaamse raadsvoorzitters baseren we ons op het Gemeentedecreet en putten we uit de bestaande literatuur.

Het vervolg van dit artikel is als volgt opgebouwd. Eerst (paragraaf 3) bespreken we de bevoegdheid van de gemeenteraad om uit zijn midden een eigen vicevoorzitter aan te wijzen en de overwegingen die daarachter liggen. Vervolgens (paragraaf 4) gaan we in op de belangrijkste taken en verantwoordelijkheden. In paragraaf 5 staan we stil bij de positie die ze innemen in het lokale bestel. In paragraaf 6 analyseren we hoe raadsleden en griffiers oordelen over de functie. We sluiten af met een conclusie en discussie (paragraaf 7).

\section{De bevoegdheid van de gemeenteraad}

De burgemeester zit de gemeenteraad voor. Dit wordt bepaald in artikel 9 Gemeentewet. Het waarnemend raadsvoorzitterschap bij verhindering of ontstentenis van de burgemeester wordt vervolgens, sinds de dualisering van het gemeentebestuur in 2002, geregeld in artikel 77 lid 1 Gemeentewet. Het betreft hier een vervanging die 'alle aspecten van het voorzitterschap' omvat (Kamerstukken II 2003/04, 29310, 6), dat wil zeggen dat alle taken die tot de burgemeester behoren in zijn hoedanigheid als raadsvoorzitter worden waargenomen door de vicevoorzitter. Maar de overige taken van de burgemeester worden waargenomen door een door het college aan te wijzen wethouder, ofwel de locoburgemeester. De waarnemend raadsvoorzitter heeft daarmee in die functie wettelijk gezien alleen een rol als de burgemeester afwezig is (Kamerstukken II 2004/05, 30008, 1, bijlage 1).

In de praktijk wordt de rol van de vicevoorzitter echter vaak veelomvattender uitgelegd. Daarvoor zijn ten minste drie redenen. In de eerste plaats moet de vicevoorzitter de burgemeester in diens afwezigheid adequaat kunnen vervangen en op ieder moment kunnen instappen. Daarom betrekken veel gemeenten de vicevoorzitter bij de voorbereidende handelingen die de burgemeester verricht in zijn rol als raadsvoorzitter. Mocht de burgemeester dan onverhoopt afwezig zijn, dan weet zijn plaatsvervanger wat er speelt en kan hij het raadsvoorzitterschap soepel overnemen. In de tweede plaats zien we de vicevoorzitter met enige regelmaat het technisch voorzitterschap van de gemeenteraadsvergadering op zich nemen op het moment dat een burgemeester als portefeuillehouder zijn beleid verdedigt. Daaraan kan behoefte bestaan omdat de burgemeester anders het woord voert en tegelijk moet voorzitten, en dat is op z'n minst een ongemakkelijke dubbelrol. Verderop in dit artikel bespreken we die in meer detail. In de derde plaats zien we dat veel gemeenten een aantal aanvullende taken logisch bij het vicevoorzitter- 
schap van de gemeenteraad vinden passen, zoals het voorzitterschap van de werkgeverscommissie van de griffier, al zijn er op dat punt grote verschillen, die we verderop in dit artikel bespreken.

Artikel 77 lid 1 Gemeentewet bepaalt daarbij dat het voorzitterschap van de gemeenteraad wordt waargenomen door het langstzittende lid van de raad, tenzij de raad een ander lid met de waarneming belast. Omgekeerd gesteld heeft de gemeenteraad dus de bevoegdheid om uit zijn midden een waarnemend raadsvoorzitter aan te wijzen. Doet hij dit niet, dan wordt het voorzitterschap van de gemeenteraad bij verhindering of ontstentenis van de burgemeester waargenomen door het langstzittende lid van de raad. De raad is 'volstrekt vrij' in de keuze van een waarnemend voorzitter uit zijn midden (Kamerstukken II 2004/05, 30008). De wetgever heeft daarbij, anders dan bij de Vlaamse gemeenteraadsvoorzitter, wel vastgehouden aan de standaardvoorziening dat in principe het langstzittende gemeenteraadslid de burgemeester vervangt.

Buiten het feit dat de stemming over personen voor het doen van benoemingen ingevolge artikel 31 Gemeentewet geheim is en dus schriftelijk gebeurt, ligt er over het keuzeproces met betrekking tot de vicevoorzitter wettelijk niets vast. Zo kan het dat in sommige gemeenten in de coalitieonderhandelingen wordt bepaald wie de vicevoorzitter wordt en in andere gemeenten wordt gewerkt met een sollicitatieprocedure binnen de raad.

De wettelijke aanduiding voor het raadslid dat de burgemeester bij verhindering of ontstentenis vervangt, is de 'waarnemend raadsvoorzitter'. In de praktijk zijn ook andere termen gangbaar, zoals 'plaatsvervangend raadsvoorzitter' of 'vicevoorzitter'. In dit artikel kiezen we voor de term 'vicevoorzitter'. Dat doen we omdat deze term naar onze overtuiging het meest recht doet aan het feit dat er rondom deze rol een aantal specifieke vragen speelt, bijvoorbeeld met betrekking tot de samenwerking met de burgemeester, de griffier en andere raadsleden. Voor een goede behandeling van die vragen is een scherp onderscheid nodig tussen de verschillende rollen en verantwoordelijkheden, dat met de term 'vicevoorzitter' wordt geboden (zie ook Kamerstukken II 2004/05, 30008, 1, bijlage 1). Dat laat onverlet dat het hier formeel gaat om waarneming; de burgemeester is en blijft immers de voorzitter van de gemeenteraad.

\subsection{Gebruik van de bevoegdheid}

In Nederland wordt veelvuldig gebruikgemaakt van de bevoegdheid een vicevoorzitter aan te wijzen. Volgens $52 \%$ van de gemeenteraadsleden en $69 \%$ van de griffiers die hebben deelgenomen aan ons onderzoek heeft de gemeenteraad in de betreffende gemeente gebruikgemaakt van zijn bevoegdheid om een ander gemeenteraadslid dan het langstzittende lid te benoemen tot waarnemend raadsvoorzitter. Op basis van deze gegevens kunnen we veilig concluderen dat een meerderheid van de destijds 388 Nederlandse gemeenteraden van deze bevoegdheid gebruik heeft gemaakt. Het precieze percentage blijft evenwel onduidelijk, omdat we vanwege de geboden anonimiteit niet weten uit welke gemeente elke respondent komt. Bovendien zijn raadsleden uit gemeenten onder de 20.000 
Tabel 1 Overwegingen bij het benoemen van een vicevoorzitter

\begin{tabular}{lll}
\hline & Aantal & Percentage \\
\hline Persoonlijke kwaliteiten van het betreffende lid & 443 & $43,5 \%$ \\
Partijpolitieke overwegingen & 278 & $27,3 \%$ \\
Anciënniteit (aantal jaar ervaring als raadslid) & 178 & $17,5 \%$ \\
Het draagvlak voor de vicevoorzitter vergroten door hem/haar bewust & 128 & $12,6 \%$ \\
aan te wijzen & & \\
Opportuniteit (bijv. er bood zich iemand aan) & 95 & $9,3 \%$ \\
De wens om het vicevoorzitterschap te combineren met het voorzit- & 89 & $8,7 \%$ \\
terschap van het presidium & & \\
Senioriteit (leeftijd) & 73 & $7,2 \%$ \\
Het versterken van de eigenstandige positie van de raad ten opzichte & 58 & $5,7 \%$ \\
van het college & & \\
Anders, namelijk: & 203 & $19,9 \%$ \\
Weet niet & 52 & $5,1 \%$ \\
Totaal & 1.019 & $100 \%$ \\
\hline
\end{tabular}

inwoners ondervertegenwoordigd onder onze respondenten. Daarnaast geven verschillende raadsleden in onze enquête aan niet op de hoogte te zijn van het bestaan van deze bevoegdheid van de gemeenteraad en stelt $7 \%$ van de raadsleden het antwoord op deze vraag niet te weten - voor griffiers is dat $1 \%$.

\subsection{Overwegingen achter het gebruik van de bevoegdheid}

Wanneer de gemeenteraad gebruik heeft gemaakt van zijn bevoegdheid om een ander lid als vicevoorzitter aan te wijzen, dan waren blijkens onze enquêteresultaten de belangrijkste overwegingen daarbij (a) de persoonlijke kwaliteiten van het betreffende raadslid, (b) partijpolitieke overwegingen en (c) anciënniteit, dat wil zeggen het aantal jaar ervaring als raadslid.

Het versterken van de eigenstandige positie van de raad ten opzichte van het college, dat in Vlaanderen een van de belangrijkste redenen is geweest om de raad de mogelijkheid te geven een raadslid als voorzitter aan te wijzen (Buylen e.a., 2014), scoort met 5,7\% relatief laag. In plaats daarvan staat het kwaliteitsoordeel over de persoon voorop, gevolgd door partijpolitieke overwegingen. In die laatste categorie zien we dat de functie vaak vrijwel automatisch aan de grootste fractie in de gemeenteraad wordt toegewezen. Een fors kleiner deel van de betreffende raadsleden geeft aan dat juist bewust een lid van de grootste oppositiepartij is aangewezen. Ook veel van de 'anders'-overwegingen duiden op dat soort politieke, zij het niet per se partijpolitieke, overwegingen. De functie van vicevoorzitter lijkt soms te worden gezien als 'politiek wisselgeld' in de coalitieonderhandelingen: de positie wordt met enige regelmaat uitgeruild tegen andere onderhandelingspunten. 


\subsection{Overwegingen om geen gebruik te maken van de bevoegdheid}

Maakte de gemeenteraad geen gebruik van zijn bevoegdheid om een vicevoorzitter te benoemen, dan was volgens $57,9 \%$ van de raadsleden en $65,2 \%$ van de griffiers de reden daarvoor dat de gemeenteraad besloot het langstzittende lid als vicevoorzitter aan te willen wijzen en het daarom niet nodig was om gebruik te maken van deze bevoegdheid. Volgens $36,6 \%$ van deze respondenten is er in de betreffende gemeenten niet gesproken over deze bevoegdheid c.q. werd het beschouwd als een formaliteit. In totaal geven 253 van de 1972 respondenten dit antwoord, ofwel $12,8 \%$. In totaal weet $4,8 \%$ van onze respondenten niet waarom geen gebruik is gemaakt van de bevoegdheid. We treffen in dezen geen statistisch significante verschillen aan tussen vicevoorzitters, overige raadsleden en griffiers. Uit het bovenstaande kunnen we concluderen dat een op de acht van onze respondenten stelt dat er geen bewuste afweging is gemaakt ten aanzien van het al dan niet zelf benoemen van de vicevoorzitter.

\section{Taken en verantwoordelijkheden}

De taak van de Nederlandse vicevoorzitter betreft formeel alleen waarneming. In de praktijk blijft het daar evenwel vaak niet bij en is de functie breder. Ze bestaat uit de volgende taken: (a) het waarnemend raadsvoorzitterschap, (b) het soms technisch voorzitten van (een deel van) de gemeenteraadsvergadering en (c) een variërend aantal bijkomende functies, waaronder het voorzitten van commissievergaderingen. We bespreken deze hieronder in meer detail. Daarnaast kijken we in deze paragraaf naar de verantwoordelijkheden die vicevoorzitters worden toegedicht.

\section{- Ad a. Waarnemend raadsvoorzitterschap}

De vicevoorzitter vervangt de burgemeester bij diens verhindering of ontstentenis. Het betreft een vervanging in alle aspecten van het burgemeestersambt voor zover die het voorzitterschap van de raad betreffen. Dit omvat, naast het feitelijk voorzitten van de raadsvergadering, mede 'de convocatie, de vaststelling van de agenda en de ondertekening van de genomen raadsbesluiten' en het ondertekenen van de van de raad uitgaande stukken (Kamerstukken II 2004/05, 28995, C). In de praktijk komt het over het algemeen maar één of enkele keren per jaar voor dat de vicevoorzitter de burgemeester in deze rol vervangt (figuur 1). Ook bij bijvoorbeeld werkbezoeken of in overleggen die de burgemeester vanuit zijn rol als raadsvoorzitter bijwoont, zien we de vicevoorzitter de burgemeester in de praktijk zelden tot nooit vervangen (figuur 2). Burgemeesters zijn simpelweg niet vaak onverhoopt afwezig. In een enkele gemeente is het gebruikelijker dat de vicevoorzitter de burgemeester vervangt, bijvoorbeeld bij raadsexcursies.

De vicevoorzitter heeft echter ook een aantal taken dat niet door de burgemeester kan worden vervuld. Denk bijvoorbeeld aan het voorzitten van de installatiever- 
Figuur 1 Hoe vaak vervangt de vicevoorzitter de burgemeester in de praktijk in het fractievoorzittersoverleg of vergelijkbare overleggen?

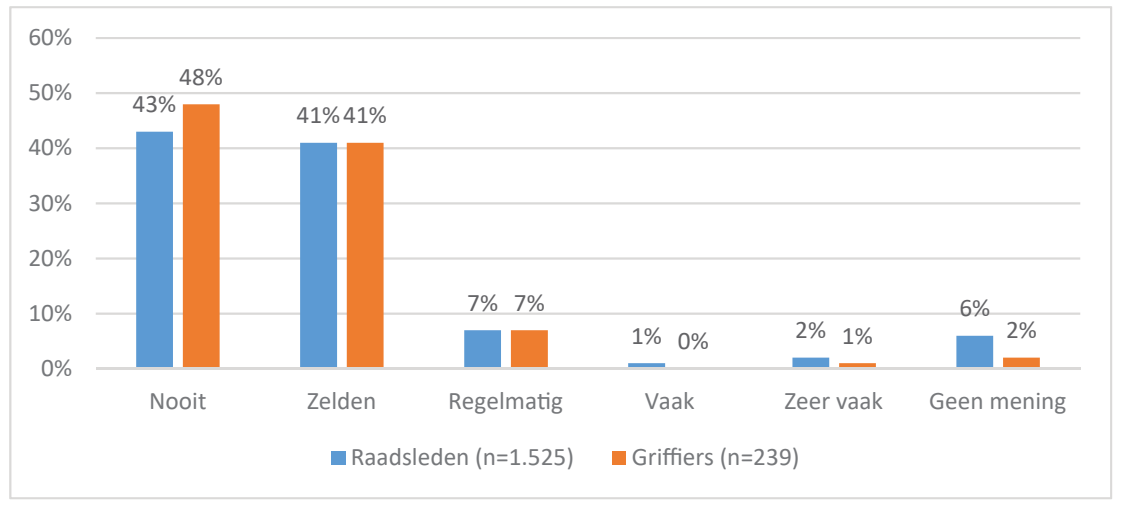

Figuur 2 Hoe vaak vervangt de vicevoorzitter de burgemeester in de praktijk bij werkbezoeken of andere vertegenwoordigende activiteiten?

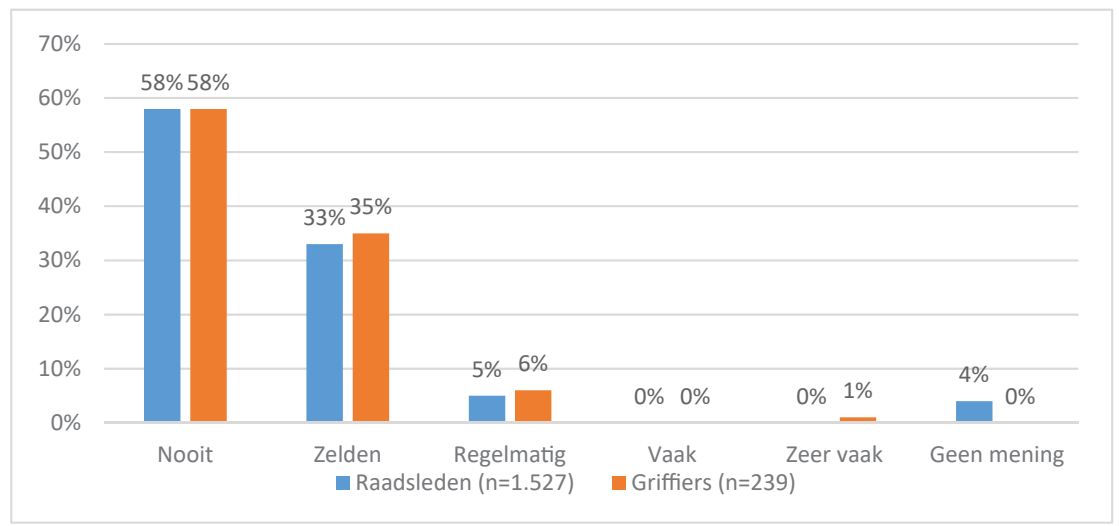

gadering van de nieuwe burgemeester of het toespreken van een vertrekkend burgemeester.

- Ad b. Technisch voorzitterschap

Ook in het geval dat de burgemeester niet verhinderd is, en formeel gehouden is de gemeenteraadsvergadering voor te zitten, neemt de vicevoorzitter in de praktijk soms het voorzitten van (een deel van) de gemeenteraadsvergadering op zich. Dat gebeurt vooral wanneer de inhoudelijke portefeuilles van de burgemeester aan de orde zijn, bijvoorbeeld OOV. Omdat de burgemeester dan als portefeuillehouder zijn beleid verdedigt, kan hij moeilijk tegelijkertijd als voorzitter fungeren en wordt het technisch voorzitterschap voor een deel van de vergadering soms overgedragen aan de vicevoorzitter. De burgemeester draagt dan het woord over aan de vicevoorzitter of maakt zelfs letterlijk plaats, om zo de rolwisseling te markeren. 
Figuur 3 Hoe vaak zit de vicevoorzitter in uw gemeente (een deel van) de gemeenteraadsvergadering voor als de OVV-portefeuille van de burgemeester aan de orde is?

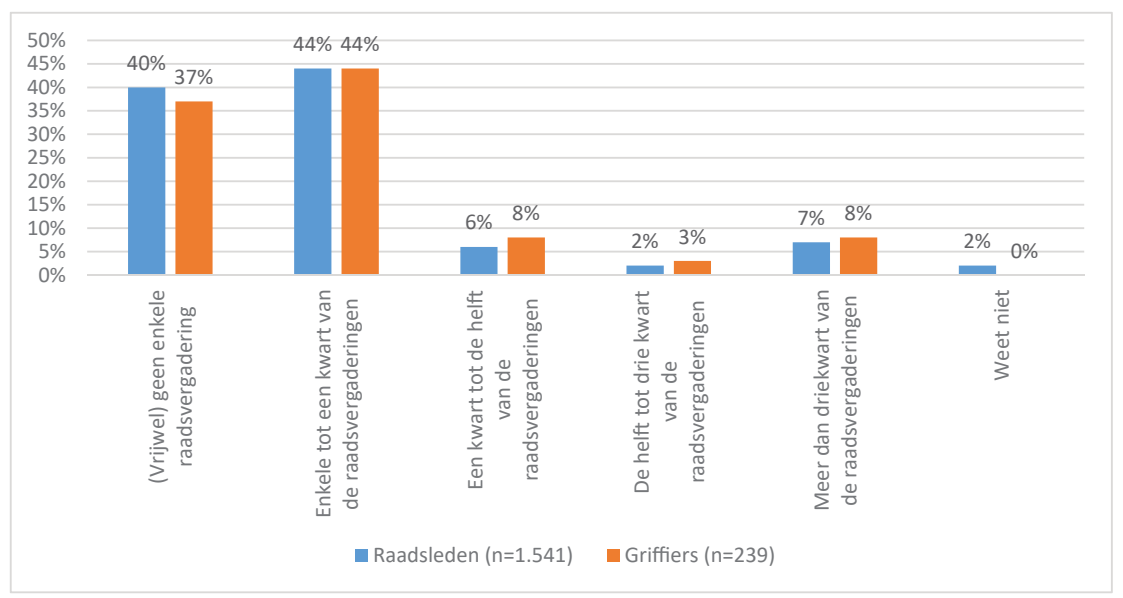

In de overgrote meerderheid van de gemeenten zit de vicevoorzitter evenwel vrijwel geen enkele tot een kwart van die vergaderingen (deels) voor. Slechts in zo'n $8 \%$ van de gemeenten zit de vicevoorzitter meer dan driekwart van de raadsvergaderingen waarin OOV wordt besproken voor een deel voor. Gemeentegrootte speelt hier een rol: hoe groter de gemeente, hoe vaker het voorkomt dat een vicevoorzitter (een deel van) de raadsvergadering voorzit als de OOV-portefeuille van de burgemeester aan de orde is. ${ }^{2}$ Het is echter ook in grotere gemeenten geen vanzelfsprekendheid dat de vicevoorzitter deze delen van de raadsvergadering voorzit. Bijna $80 \%$ van de respondenten actief in gemeenten groter dan 50.000 inwoners geeft aan dat de vicevoorzitter in vrijwel geen tot een kwart van de raadsvergaderingen waarin de OOV-portefeuille aan de orde is, een deel van de vergadering voorzit (figuur 3 ).

Ook wanneer zijn andere politieke portefeuilles worden besproken, kan de burgemeester het technisch voorzitterschap van een deel van de gemeenteraadsvergadering overdragen aan de vicevoorzitter. 'De burgemeester heeft ook andere zaken in portefeuille en dan vervangt de vicevoorzitter hem natuurlijk ook', zo stelt een griffier in onze enquête. Deze manier van werken komt echter in zo'n $80 \%$ van de gemeenten nooit voor. Volgens een op de zeven respondenten gebeurt het wel regelmatig, en volgens een enkele respondent zelfs vaak tot zeer vaak (figuur 4). Gemeentegrootte maakt hier wederom verschil. Hoe groter de gemeente, hoe vaker het voorkomt dat de vicevoorzitter de raadsvergadering

$2 \chi^{2}(4, \mathrm{n}=1.756)=114.86, \mathrm{p}<.001$. Behalve tussen respondenten uit gemeenten tot 10.000 inwoners en respondenten uit gemeenten tussen 10.000 en 20.000 inwoners zijn de verschillen statistisch significant $(\mathrm{p}<.05)$, na toepassing van een Bonferroni-correctie. 
Figuur 4 Hoe vaak vervangt de vicevoorzitter de burgemeester in de praktijk als voorzitter van de gemeenteraadsvergadering buiten de OVVportefeuille om?

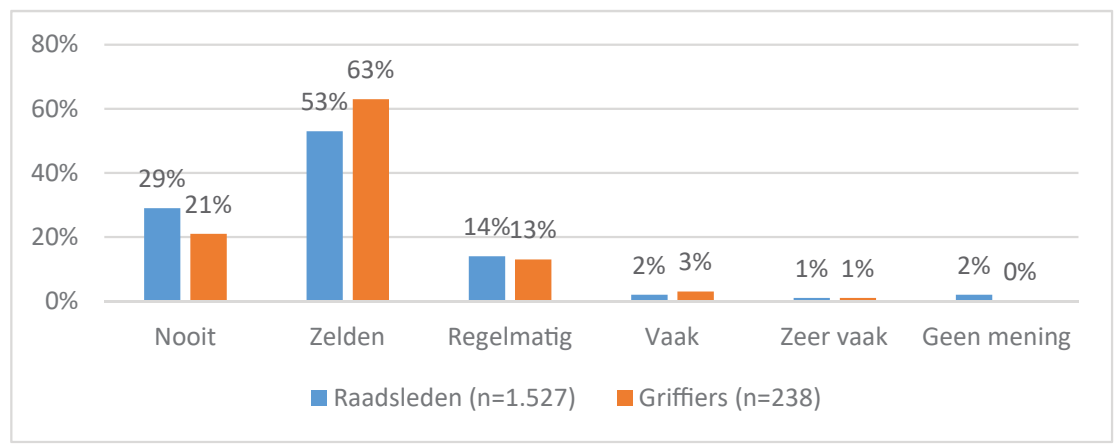

voorzit als een portefeuille van de burgemeester, buiten de OOV-portefeuille om, aan de orde is. ${ }^{3}$

Dat de burgemeester het technisch voorzitterschap overdraagt aan de vicevoorzitter is dan ook zeker geen vanzelfsprekendheid. In de praktijk blijkt het antwoord op deze vraag, zo leren onze focusgroepgesprekken, sterk af te hangen van hoe de burgemeester persoonlijk aankijkt tegen het wel of niet overdragen van het technisch voorzitterschap.

\section{- Ad c. Bijkomende functies}

Naast de vervanging bij afwezigheid en het tijdelijk overnemen van het technisch voorzitterschap van de gemeenteraadsvergadering, constateren we dat vicevoorzitters in een groot aantal gemeenten bijkomende functies hebben die volgens de lokale gebruiken tot het takenpakket van de vicevoorzitter behoren. Zo zien we vergadermodellen waarin de vicevoorzitter standaard de commissievergaderingen en/of de opiniërende raadsvergaderingen voorzit. In dat laatste geval zit de burgemeester alleen de besluitvormende gemeenteraadsvergaderingen voor. Daarbij zien we dat de vicevoorzitter met enige regelmaat uit hoofde van die functie deelneemt aan het presidium - het dagelijks bestuur van de gemeenteraad. In ongeveer een op de zeven gemeenten is de vicevoorzitter ook de voorzitter van het presidium, maar dat hangt niet noodzakelijk samen met het vicevoorzitterschap dat kan bijvoorbeeld ook zijn omdat hij tevens fractievoorzitter is van de grootste partij in de raad. Ook wordt de vicevoorzitter met enige regelmaat genoemd als voorzitter van een afzonderlijke agendacommissie. Verder wordt regelmatig aangegeven dat de vicevoorzitter de werkgeverscommissie van de griffier voorzit en/ of dat hij de vertrouwenscommissie voorzit bij benoeming of herbenoeming van

$3 \chi^{2}(4, \mathrm{n}=1.731)=33.23, \mathrm{p}<.001$. Het verschil tussen gemeenten kleiner dan 50.000 inwoners en gemeenten met 100.000 inwoners of meer is statistisch significant $(p<.05)$, na toepassing van een Bonferroni-correctie. 
de burgemeester en bij het voeren van de klankbordgesprekken met de burgemeester. Het lidmaatschap van de rekenkamercommissie wordt eveneens een enkele keer genoemd als onderdeel van het vicevoorzitterschap. Naast deze (veelvoorkomende) functiecombinaties bestaan er nog allerlei tussenvarianten, met steeds een net iets andere rol voor de vicevoorzitter. We zien dus een grote verscheidenheid aan functieprofielen en constateren dat er lokaal heel verschillend invulling wordt gegeven aan de functie van vicevoorzitter. De verscheidenheid is zo groot dat het niet goed mogelijk is om na te gaan in hoeveel Nederlandse gemeenten elk model wordt gehanteerd.

\subsection{Verantwoordelijkheden van de vicevoorzitter}

Naast het bepalen van de formele taken die een vicevoorzitter heeft, is het ook relevant om na te gaan welke verantwoordelijkheden hem worden toegeschreven. Die zijn immers niet noodzakelijk allemaal formeel vastgelegd. Om de verantwoordelijkheden van vicevoorzitters beter te kunnen duiden, hebben we raadsleden en griffiers een elftal taken voorgelegd en hun gevraagd hoe belangrijk de rol van de vicevoorzitter bij deze activiteiten is.

Niet geheel onverwacht is de belangrijkste verantwoordelijkheid van de vicevoorzitter die van het voorzitten van de raadsvergadering in afwezigheid van de burgemeester dan wel ter vervanging van de burgemeester. Omdat die verantwoordelijkheid hierboven al uitgebreid aan de orde is geweest, bespreken we die hier niet nogmaals. Als belangrijkste verantwoordelijkheden volgen daarna 'het bewaken van de integriteit', 'het bewaken van de kwaliteit van de besluitvorming in de gemeenteraad' en 'het overleggen met fractievoorzitters/seniorenoverleg/presidium'. De overige verantwoordelijkheden scoren bij raadsleden gemiddeld onder de 2,00 op een vierpuntsschaal en worden daarmee niet erg belangrijk tot niet belangrijk geacht.

Het bewaken van de integriteit. De belangrijkste verantwoordelijkheid voor het bevorderen van de bestuurlijke integriteit van de gemeente ligt, ingevolge artikel 170 lid 2 Gemeentewet, bij de burgemeester. Zowel uit onze enquête als uit onze gesprekken blijkt evenwel dat ook de vicevoorzitter van de gemeenteraad in dezen in de praktijk een belangrijke verantwoordelijkheid draagt. Die verantwoordelijkheid is tweeledig. In de eerste plaats is de vicevoorzitter vaak een sparringpartner voor de burgemeester als er vermoedens van integriteitsschendingen rijzen met betrekking tot gemeenteraadsleden. In de tweede plaats fungeert de vicevoorzitter als aanspreekpunt voor anderen als de integriteit van de burgemeester in het geding is. Die rol zien we in ten minste een aantal gemeenten ook geformaliseerd in gedragscodes, waarin de processtappen bij (vermoedens van) integriteitsschendingen zijn vastgelegd.

Het bewaken van de kwaliteit van de besluitvorming in de gemeenteraad. In het verlengde van de verantwoordelijkheid van de burgemeester voor het bewaken van de kwaliteit van de besluitvorming in de gemeenteraad wordt de vicevoorzitter in onze enquête op dit punt ook een belangrijke verantwoordelijkheid toegedicht. 
Tabel 2 Belang van verantwoordelijkheden van de vicevoorzitter (1'niet belangrijk' - 4 'zeer belangrijk')

\begin{tabular}{lll}
\hline & $\begin{array}{l}\text { Gemid- } \\
\text { delde vice- } \\
\text { voorzitters }\end{array}$ & $\begin{array}{l}\text { Gemid- } \\
\text { delde } \\
\text { raadsleden }\end{array}$ \\
\hline Voorzitten van de raadsvergadering & 3,08 & 2,76 \\
Bewaken van de integriteit & 2,76 & 2,28 \\
Bewaken van de kwaliteit van de besluitvorming in de raad & 2,66 & 2,19 \\
Overleggen met fractievoorzitters/seniorenoverleg/presidium & 2,37 & 2,09 \\
Bemiddelen in conflicten & 2,33 & 1,90 \\
Afleggen van verantwoording & 2,20 & 1,91 \\
Opstellen van de raadsagenda & 2,06 & 1,83 \\
Coachen van raadsleden & 1,97 & 1,60 \\
Voorbereiden van commissievergaderingen & 1,91 & 1,73 \\
Verwerven van draagvlak voor beleid & 1,87 & 1,64 \\
Richting geven aan beleid & 1,79 & 1,58 \\
\hline
\end{tabular}

Die verantwoordelijkheid strekt verder dan het technisch voorzitten van delen van gemeenteraadsvergaderingen alleen. In verschillende gemeenten is de vicevoorzitter een belangrijke counterpart van de burgemeester, daar waar het de inrichting van het besluitvormingsproces of de bespreking in de raad betreft, in het geval van belangrijke en/of politiek gevoelige dossiers.

Het overleggen met fractievoorzitters/seniorenoverleg/presidium. In het overleggen met fractievoorzitters, dan wel het seniorenoverleg of het presidium, wordt aan vicevoorzitters eveneens een belangrijke verantwoordelijkheid toegeschreven. Eerder gaven we al aan dat de variëteit aan vergadermodellen zo groot is dat het moeilijk is om op dit punt algemene uitspraken te doen. We zien wel dat het over het algemeen belangrijk wordt gevonden dat er sprake is van een functionele verbinding tussen de verschillende overleggen rondom de inrichting van de besluitvorming in de gemeenteraad. De vicevoorzitter kan daarin een belangrijke schakel vormen. Dat is voor de burgemeester soms moeilijker, omdat die nu eenmaal ook voorzitter is van het college.

\section{De positie van de vicevoorzitter}

Wat, blijkens de gevoerde gesprekken, vooral belangrijk is voor vicevoorzitters is dat zij gezag hebben in de gemeenteraad. De vicevoorzitter moet iemand zijn met 'een zekere statuur' in de raad, zo verwoordde een griffier het. Het moet iemand zijn die kan bogen op 'natuurlijk gezag' en die het respect van de raad heeft, zo gaven raadsleden aan. Een vicevoorzitter moet immers een aanspreekpunt kunnen zijn voor anderen, anderen kunnen aanspreken en ook een zekere doorzettingsmacht hebben. Uit de gevoerde gesprekken blijkt het daarbij vooral belangrijk dat vicevoorzitters in hun functie politiek onafhankelijk optreden en oorde- 
len. Ze moeten in hun rol als voorzitter zogezegd boven de partijen staan en politiek neutraal kunnen handelen. Daarmee raken we meteen aan een van de ingewikkeldheden aan de rol van de vicevoorzitter. De vicevoorzitters is immers altijd gemeenteraadslid en daarmee per definitie niet volledig (partij)politiek onafhankelijk. Dat brengt vicevoorzitters in een lastig parket, zo blijkt niet alleen uit onze enquête, maar ook uit de gevoerde gesprekken. De ingewikkeldheid rondom onafhankelijkheid werkt twee kanten op: het is de vraag of vicevoorzitters voldoende politiek neutraal kunnen handelen, maar ook of zij zich als gemeenteraadslid nog voldoende politiek kunnen profileren. Deze ingewikkeldheden gelden vooral voor fractievoorzitters, zo blijkt.

Het is voor vicevoorzitters niet altijd gemakkelijk om politiek neutraal te zijn en te blijven, niet alleen omdat ze altijd ook partijpoliticus zijn, maar ook omdat ze door mederaadsleden en anderen altijd als partijpoliticus gezien worden. En het is dan ook niet altijd gemakkelijk die twee rollen van elkaar te scheiden, voor henzelf niet noch in de beleving van anderen. Verschillende vicevoorzitters geven aan op dit punt moeilijkheden te ervaren. Het is 'lastig om politiek neutraal te zijn, [terwijl je] dat wel moet zijn, vind ik', geeft een van hen aan. Ook in het focusgroepgesprek met vicevoorzitters is uitgebreid over dit punt gesproken, omdat het van de betreffende raadsleden vraagt dat ze op momenten terughoudend zijn in hun optreden als lid van een politieke fractie. Ze kunnen soms net iets minder spontaan reageren in een politiek debat, omdat ze rekening moeten houden met het feit dat ze ook vicevoorzitter zijn. Dat geldt natuurlijk vooral voor die delen van de gemeenteraadsvergadering die ze zelf voorzitten - daar kunnen ze inhoudelijk bijna niet aan bijdragen. Maar ook breder moeten ze ervoor waken dat ze, tenminste in hun functie als vicevoorzitter, voldoende politiek neutraal kunnen blijven optreden. Van de vicevoorzitters zelf geeft uiteindelijk overigens maar $2 \%$ aan dit als knelpunt te ervaren.

Vragen we gemeenteraadsleden en griffiers of de vicevoorzitter in hun gemeente voldoende politiek neutraal is, dan krijgen we een heel divers beeld (figuur 5). Griffiers zien op dit punt over het algemeen weinig problemen: $82 \%$ van hen is het met deze stelling (helemaal) eens. Ook van de raadsleden is een meerderheid het (helemaal) eens met deze stelling, maar onder hen is een forse minderheid van $30 \%$, die vindt dat de vicevoorzitter in hun gemeente onvoldoende politiek neutraal is. ${ }^{4}$ Raadsleden van coalitiepartijen zijn daarbij vaker van mening dat de vicevoorzitter voldoende politiek neutraal is dan raadsleden van oppositiepartijen. ${ }^{5}$ Bovendien zijn er kleine verschillen op basis van gemeentegrootte: respondenten uit gemeenten groter dan 100.000 inwoners zijn positiever over de poli-

4 Het verschil in opvatting tussen griffiers en raadsleden is statistisch significant $(\mathrm{U}=116464, \mathrm{z}=$ $-6.1, \mathrm{p}<.001, \mathrm{r}=.15)$. Griffiers ( $\mathrm{Md}=3, \mathrm{M}=3.14, \mathrm{n}=216$ ) zijn het vaker eens met de stelling dat de vicevoorzitter voldoende politiek neutraal is dan raadsleden ( $M d=3, M=2.75, n=1.380$ ).

5 Het verschil tussen raadsleden van coalitiepartijen en raadsleden van oppositiepartijen is statistisch significant $(\mathrm{U}=188956, \mathrm{z}=-5.6, \mathrm{p}<.001, \mathrm{r}=.15)$. Raadsleden van coalitiepartijen $(\mathrm{Md}=3$, $\mathrm{M}=2.86, \mathrm{n}=832$ ) zijn het vaker met de stelling eens dat de vicevoorzitter voldoende politiek neutraal is dan raadsleden van oppositiepartijen ( $M d=3, M=2.59, n=545)$. 


\section{Figur 5 Onze vicevoorzitter is voldoende politiek neutraal.}

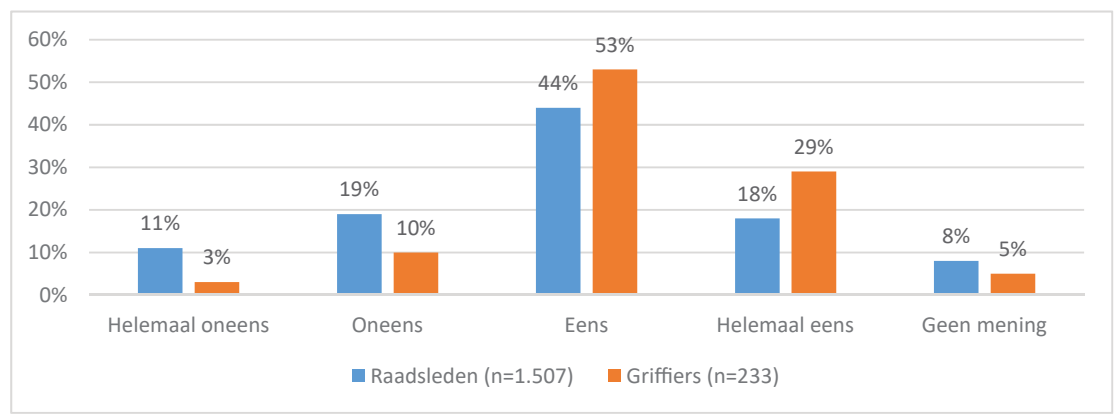

tieke neutraliteit van de vicevoorzitter dan respondenten uit gemeenten tot 10.000 inwoners en respondenten uit gemeenten van 20.000 tot 50.000 inwoners. ${ }^{6}$ De politieke onafhankelijkheid van vicevoorzitters lijkt daarmee in ieder geval een punt van aandacht te zijn.

In de tweede plaats zien we dat de ingewikkeldheid rondom hun politieke onafhankelijkheid voor vicevoorzitters ook de andere kant op werkt. Vicevoorzitters worden geacht politiek neutraal te zijn en kunnen zich daardoor soms minder sterk politiek profileren dan ze zelf misschien zouden willen. '[Het vicevoorzitterschap] gaat ten koste van mijn politieke profiel als raadslid en verzwakt de fractie', zo stelt een van hen. 'Het verzwakt de positie van de fractie door de gedwongen neutraliteit van de vicevoorzitter', stelt een ander.

Uit de door ons gevoerde gesprekken blijkt dat deze problematiek in beide opzichten in het bijzonder opgeld doet voor fractievoorzitters. Zij staan centraler in het politieke debat en van hen wordt eerder verwacht dat zij het politieke standpunt van de fractie naar voren brengen. Die verwachtingen kunnen botsen met de rol van vicevoorzitter van de raad. 'Ik laat zware politieke debatten aan mijn collega's, omdat het anders afbreuk kan doen aan mijn positie als voorzitter', zo stelt een van de vicevoorzitters in onze enquête. Zeker voor fractievoorzitters, en in mindere mate voor woordvoerders op een bepaald beleidsterrein, is dat niet eenvoudig. Van hen wordt immers juist een politieke inbreng in het debat verwacht. Maar de inbreng van de fractievoorzitter in het politieke debat gaat vrijwel verloren op het moment dat hij het betreffende deel van de raadsvergadering moet voorzitten, en dat laat hem minder ruimte om het politieke debat met het college en met de rest van de raad te voeren.

$6 \chi^{2}(4, \mathrm{n}=1.602)=15.90, \mathrm{p}<.01$. Het verschil tussen respondenten uit gemeenten groter dan 100.000 inwoners en respondenten uit gemeenten met 0-10.000 inwoners dan wel 20.000-50.000 inwoners is statistisch significant met $\mathrm{p}<.05$, na toepassing van de Bonferronicorrectie. 


\section{Figuur 6 De functie van vicevoorzitter van de gemeenteraad is in onze} gemeente belangrijk.

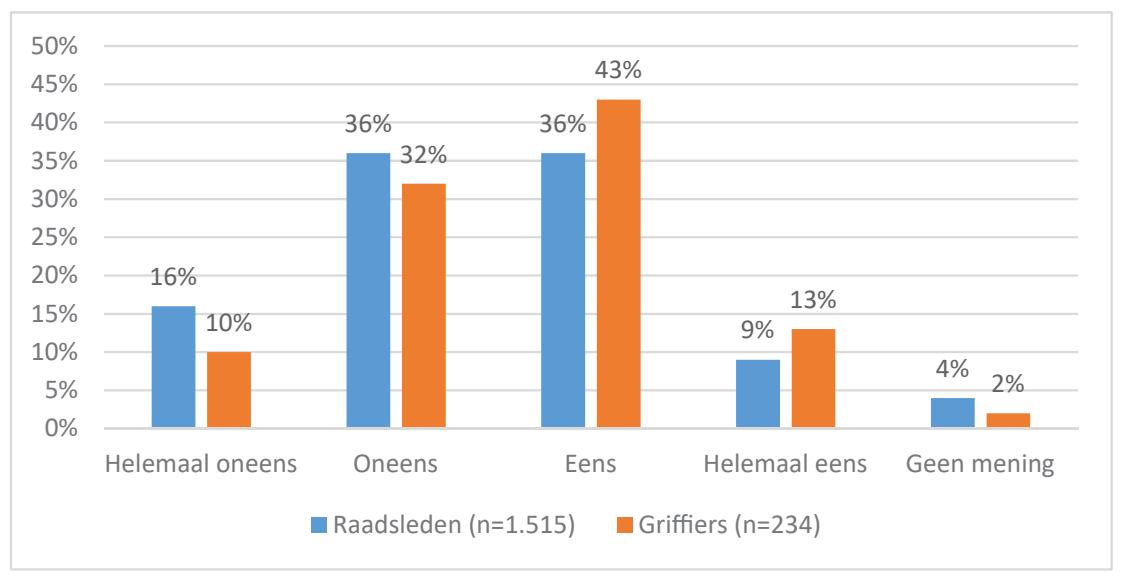

\section{Evaluatie van de functie}

In deze paragraaf kijken we naar hoe gemeenteraadsleden en griffiers de functie van vicevoorzitter evalueren. We kijken daarbij naar (a) het ervaren belang van de functie, (b) de ervaren invloed van vicevoorzitters, (c) de eventuele behoefte aan versterking van de functie en (d) de opvattingen ten aanzien van de vraag wie de gemeenteraad het beste kan voorzitten.

\section{- Ad a. Het belang van de functie}

Aan de functie van vicevoorzitter wordt gemiddeld genomen door zowel raadsleden als griffiers belang gehecht, maar de meningen verschillen sterk. Van de raadsleden in ons onderzoek is $45 \%$ het (helemaal) eens met de stelling dat de functie van vicevoorzitter in hun gemeente belangrijk is. Van de griffiers is $56 \%$ deze mening toegedaan (figuur 6).

Anders dan bij een aantal andere stellingen die we onze respondenten hebben voorgelegd, zien we hier een behoorlijke spreiding (de standaarddeviatie bedraagt .972). Dat betekent dat de meningen op dit punt flink verschillen. In de ene gemeente is de functie van vicevoorzitter dus aanzienlijk belangrijker dan in andere gemeenten. De grootte van de gemeente speelt hierin mee: in gemeenten groter dan 100.000 inwoners geven raadsleden en griffiers vaker aan dat de functie van vicevoorzitter van de gemeenteraad belangrijk is dan in gemeenten met minder dan 50.000 inwoners. ${ }^{7}$ Raadsleden en griffiers delen in dit opzicht ook

$7 \quad \chi^{2}(4, \mathrm{n}=1.689)=29.786, \mathrm{p}<.001$. Het verschil tussen respondenten uit gemeenten groter dan 100.000 inwoners en respondenten uit gemeenten kleiner dan 50.000 inwoners is statistisch significant $(\mathrm{p}<.05)$, na toepassing van de Bonferroni-correctie. 


\section{Figuur 7 De vicevoorzitter heeft veel invloed op de dagelijkse gang van zaken} rondom de raad.

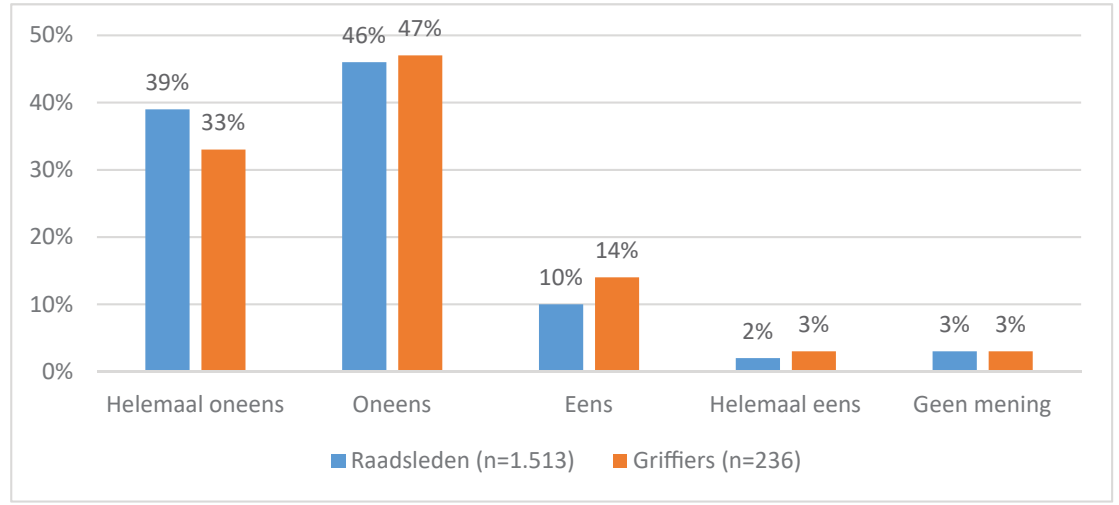

niet helemaal dezelfde mening: griffiers zijn het statistisch significant vaker dan raadsleden (helemaal) eens met de stelling dat de functie van vicevoorzitter van de gemeenteraad in hun gemeente belangrijk is. ${ }^{8}$

\section{- Ad b. De invloed van vicevoorzitters}

Hoewel er dus wezenlijk belang aan de functie wordt gehecht, moeten we de invloed van vicevoorzitters niet overschatten. Ruime meerderheden onder de raadsleden en griffiers zijn het in onze enquête oneens met de stelling dat de vicevoorzitter veel invloed heeft op de dagelijkse gang van zaken rondom de gemeenteraad (figuur 7). Die stelling wordt slechts door respectievelijk $12 \%$ en $17 \%$ van de respondenten (helemaal) onderschreven. Respondenten uit gemeenten groter dan 100.000 inwoners zijn het echter statistisch significant vaker eens met deze stelling dan respondenten uit gemeenten van 10.000 tot 50.000 inwoners. Kortom: de invloed van de vicevoorzitter lijkt groter te zijn in Nederlands grootste gemeenten. ${ }^{9}$

Evenzogoed wordt de mening dat de vicevoorzitter een bijzondere verantwoordelijkheid zou hebben voor het functioneren van de raad als eenheid onder raadsleden en griffiers niet breed gedeeld (figuur 8). Met de betreffende stelling zijn steeds meerderheden het (helemaal) oneens. Daarmee blijft de constatering van Van Ostaaijen (2016) dat die verantwoordelijkheid nergens duidelijk is belegd overeind. Er zijn echter ook auteurs die stellen dat het niet wenselijk is dat de raad eenheid uitstraalt, omdat 'de' raad als geheel niet kan bestaan vanwege het

8 Griffiers: $\mathrm{Md}=3$, raadsleden: $\mathrm{Md}=2, \mathrm{n}=1.972, \mathrm{U}=14475, \mathrm{z}=-3.566, \mathrm{p}<.05, \mathrm{r}=.08$.

$9 \chi^{2}(4, \mathrm{n}=1.697)=45.88, \mathrm{p}<.001$. Het verschil tussen respondenten uit gemeenten groter dan 100.000 inwoners en respondenten tussen 10.000 en 50.000 inwoners is statistisch significant bij $\mathrm{p}<.05$, met toepassing van de Bonferroni-correctie. 


\section{Figuur 8 De vicevoorzitter heeft een bijzondere verantwoordelijkheid voor het} functioneren van de raad als eenheid.

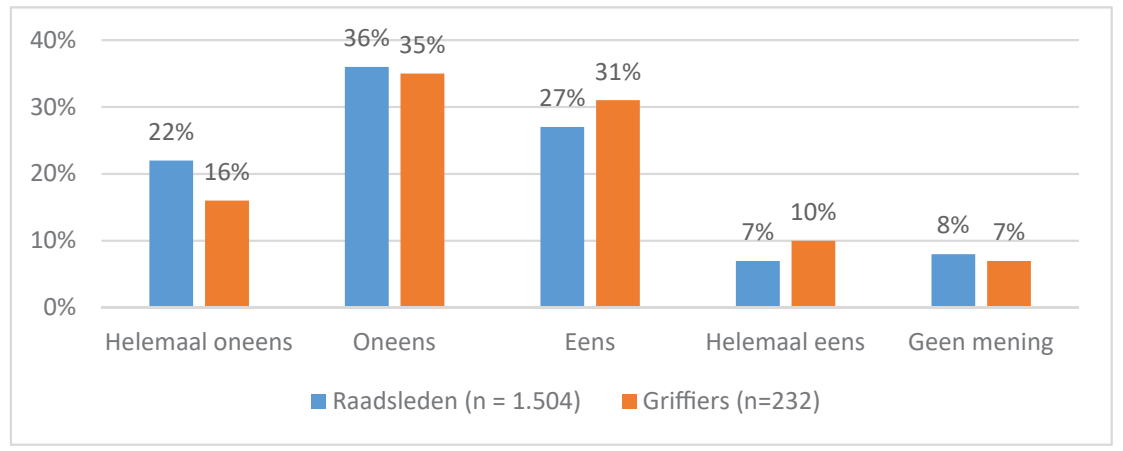

feit dat hij zijn bestaansrecht juist ontleent aan verdeeldheid en politiek meningsverschil (BMC, 2007).

Er bestaat in dezen ook een zekere differentiatie tussen respondenten. Zowel de gemeentegrootte als de positie van respondenten in de gemeente (raadslid dan wel griffier) maakt uit voor de mate waarin respondenten het eens zijn met deze stelling. Respondenten werkzaam in gemeenten groter dan 100.000 inwoners zijn het vaker eens met deze stelling dan respondenten uit gemeenten van 20.000 tot 100.00 inwoners. ${ }^{10}$ Bovendien stellen griffiers vaker dan raadsleden dat de vicevoorzitter in dit kader een bijzondere verantwoordelijkheid heeft. ${ }^{11}$

\section{- Ad c. Behoefte aan versterking van de positie}

In Vlaanderen wordt, onder andere door de Vereniging van Vlaamse Steden en Gemeenten (VVSG, 2017), hartstochtelijk gepleit voor een verdere versterking van de positie van de gemeenteraadsvoorzitter om de positie van de raad ten opzichte van het college verder te verstevigen. In Nederland treffen we een dergelijk sentiment niet aan: over het geheel genomen klinkt er geen brede roep om versterking van de positie, al is er een stevige minderheid die daar wel voor pleit (figuur 9). Van onze respondenten vindt een meerderheid van 58,4\% dat een versterking van de positie van de vicevoorzitter niet nodig is. Een minderheid van $27,5 \%$ vindt dat dit wel nodig is.

Daar waar wel behoefte bestaat aan versterking van de positie van de vicevoorzitter gaat het over het geheel genomen om drie aspecten van de functie. Er is één groep van raadsleden en griffiers die graag zou zien dat de vicevoorzitter een grotere rol zou krijgen in lokaal bestuur, bijvoorbeeld door hem een verantwoorde-

$10 \chi^{2}(4, \mathrm{n}=1.596)=19.64, \mathrm{p}<.001$. Het verschil tussen respondenten uit gemeenten van 100.000 inwoners of meer en respondenten uit gemeenten met 20.000 tot 50.000 inwoners en 50.000 tot 100.00 inwoners is statistisch significant bij $\mathrm{p}<.05$, na toepassing van de Bonferroni-correctie.

11 Griffiers: $\mathrm{Md}=2, \mathrm{n}=216$, raadsleden: $\mathrm{Md}=2, \mathrm{n}=1.380 . \mathrm{U}=164388, \mathrm{z}=2.57, \mathrm{p}=.01, \mathrm{r}=.06$. 


\section{Figuur 9 De positie van de vicevoorzitter behoeft versterking.}

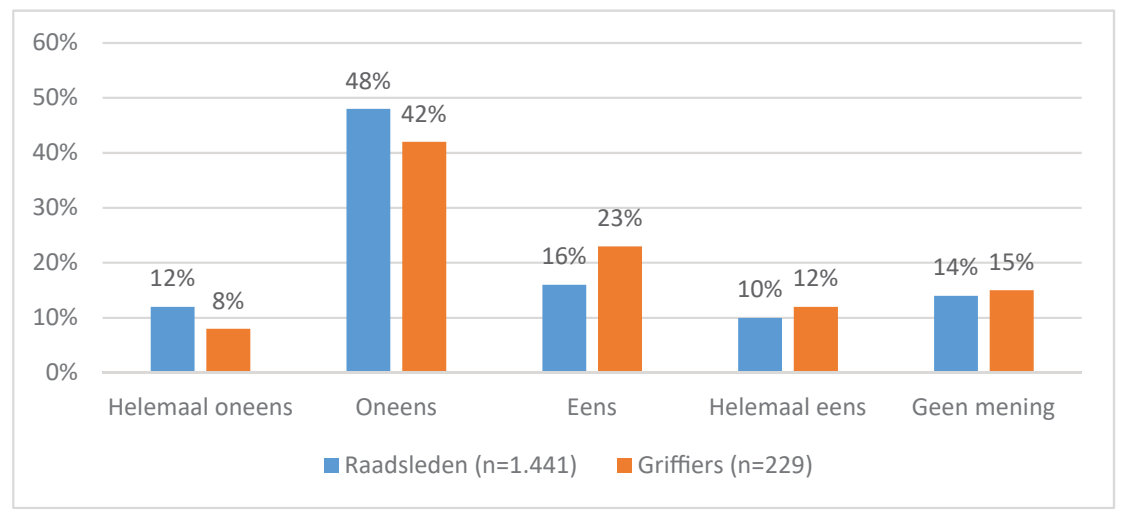

lijkheid te geven voor het functioneren van de gemeenteraad als geheel. Andere mogelijkheden zijn hem wettelijke bevoegdheden te geven in het bijeenroepen van de gemeenteraad of hem de beslissende stem te geven als de stemmen staken. Een ander aspect waarvoor versterking van de positie van de vicevoorzitter wenselijk wordt geacht, is het lokaal beter vastleggen van zijn taken, bevoegdheden en verantwoordelijkheden, bijvoorbeeld in een reglement van orde of een verordening. De Vlaamse ervaringen leren in ieder geval dat onduidelijkheid over de rol, positie en bevoegdheden van de vicevoorzitter tot problemen kan leiden (Verbeek $\&$ Van Bouwel, 2012). Een derde en laatste aspect waarop voor versterking wordt gepleit, is de training en ondersteuning van vicevoorzitters, met als doel hun vaardigheden en expertise te versterken.

\section{- Add. Geprefereerde gemeenteraadsvoorzitter}

In een ruime meerderheid van de Vlaamse gemeenten zit, zoals gezegd, een gemeenteraadslid de raad voor. In Nederland lijkt weinig steun te bestaan voor dat model. Zowel raadsleden als griffiers zien de burgemeester in meerderheid als de meest aangewezen voorzitter van de gemeenteraad. Zo'n $66 \%$ van onze respondenten is daar voorstander van, waarmee dat model onder hen bij uitstek de voorkeur geniet boven andere modellen, al zijn er hartstochtelijke voor- en tegenstanders van de verschillende opties (figuur 10).

Uit de toelichting op de antwoorden die respondenten geven, komt naar voren dat de burgemeester over het algemeen als de meest aangewezen voorzitter van de gemeenteraad wordt gezien vanwege diens 'positie boven de partijen', die zijn (partijpolitieke) onafhankelijkheid waarborgt. In dit opzicht zou een burgemeester, beter dan een raadslid, politiek neutraal kunnen blijven in zijn rol als voorzitter. Ook wordt met regelmaat gewezen op het belang van de dubbelfunctie van de burgemeester als voorzitter van gemeenteraad én college, van waaruit de burgemeester een belangrijke verbinding kan leggen tussen beide organen. 
Figuur 10 Wie zou naar uw mening de gemeenteraad het beste kunnen voorzitten?

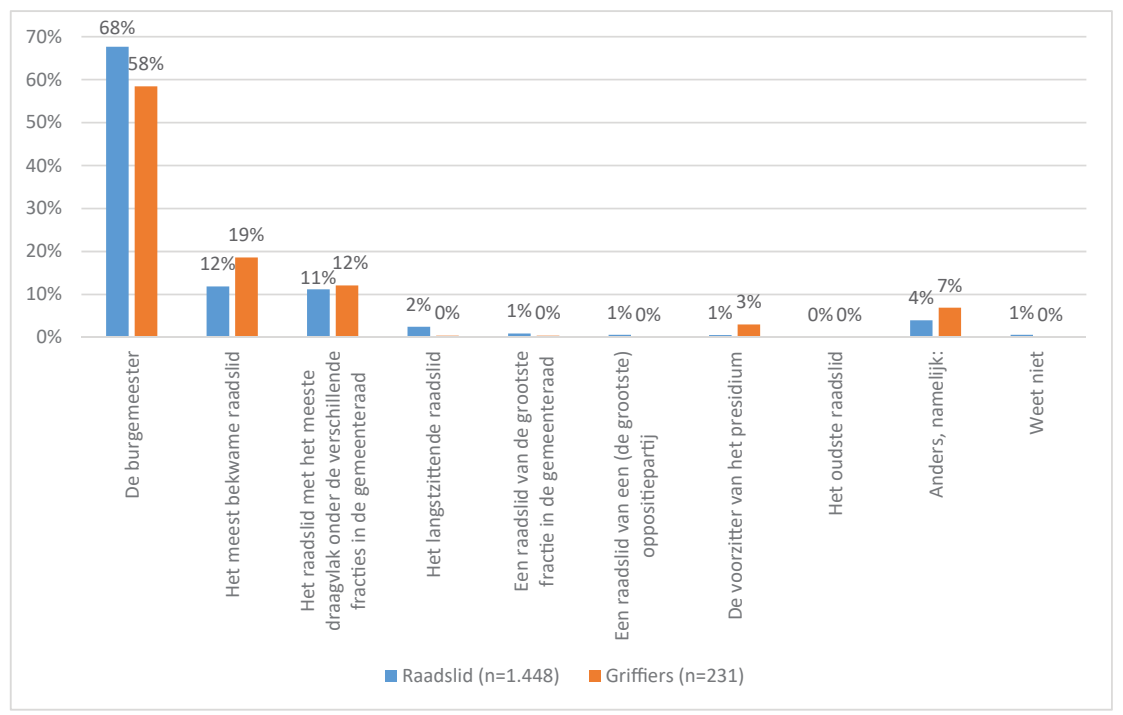

\section{Conclusie en discussie}

Ten tijde van de dualisering werd de vicevoorzitter van de gemeenteraad wel gezien als 'hoeder van de gemeenteraad', die een bijzondere verantwoordelijkheid draagt voor het functioneren van de raad als geheel en de raad een gezicht kan geven tegenover het college. Ruim vijftien jaar later is de functie echter maar beperkt ontwikkeld, zo blijkt ook uit onderhavig onderzoek. Hoewel een meerderheid van de gemeenten gebruikmaakt van de bevoegdheid om een eigen vicevoorzitter te benoemen en er belang wordt gehecht aan de functie, is de feitelijke betekenis ervan beperkt, zeker in kleinere gemeenten. Een van de respondenten in ons onderzoek typeert het vicevoorzitterschap zelfs als een 'functie zonder inhoud'. In feite wordt het vicevoorzitterschap, overeenkomstig de wettelijke bepaling, vooral opgevat als vervanging van de burgemeester in het geval dat die onverhoopt afwezig mag zijn. In de praktijk wordt de functie veelal wel veelomvattender uitgelegd, maar van een eigenstandige functie blijkt nauwelijks sprake. Evenmin lijkt er een breed gedeelde behoefte te bestaan aan uitbreiding of versteviging van de rol van de vicevoorzitter. De burgemeester wordt, althans door raadsleden en griffiers, in grote meerderheid gezien als de meest aangewezen voorzitter van de gemeenteraad.

Daarmee lijkt er op dit punt weinig behoefte te bestaan om te leren van Vlaanderen en de rol van gemeenteraadsleden bij het voorzitterschap van de gemeenteraad te vergroten. Waar de eigen voorzitter van de gemeenteraad in het monistische Vlaanderen vooral tot doel heeft de positie van de gemeenteraad ten opzichte van het college te versterken, speelt die overweging in het dualistische 
Nederland maar zeer beperkt een rol en lijkt daar ook geen behoefte aan te bestaan. Daar vertegenwoordigt de voorzittersrol primair politieke onafhankelijkheid en de functionele verbinding tussen raad en college. Een belangrijke verklaring voor dit verschil lijkt gelegen in verschillen tussen de Nederlandse en Vlaamse burgemeestersfuncties. De rol van de Vlaamse burgemeester is immers een veel politiekere, die behoefte heeft doen ontstaan aan eigenstandig leiderschap vanuit de gemeenteraad. De rol van de Nederlandse burgemeester is veel minder politiek en put juist kracht uit onafhankelijk en verbindend voorzitterschap (zie ook Karsten e.a., 2017).

De mogelijkheid om de vicevoorzitter een bijzondere verantwoordelijkheid te geven voor het functioneren van de gemeenteraad als geheel, die Van Ostaaijen (2016) oppert, vindt in Nederland dan ook weinig weerklank. Desalniettemin laat ons onderzoek zien dat er voor gemeenteraden nog aanzienlijke ruimte ligt om de functie van vicevoorzitter actiever invulling te geven. De al decennialang lopende discussie over het voorzitterschap van de gemeenteraad is immers nog lang niet geslecht (Rob, 2016b), zo laat ook de recente discussie over het externe voorzitterschap van raadscommissies zien (Kamerstukken II 2018/19, 34807). Dat vraagstuk zou bovendien weleens aan belang kunnen winnen nu de deconstitutionalisering van de aanstellingswijze van de burgemeester een feit is en een hernieuwde discussie in aantocht lijkt over de rol en functie van de burgemeester in het lokaal bestuur (Rob, 2016b). In de loop van die discussie zou het van waarde kunnen zijn om opnieuw een blik te werpen over de Nederlands-Vlaamse grens. Dat zou wel uitgebreider empirisch onderzoek vragen naar hoe Vlaamse gemeenteraden gebruikmaken van de bevoegdheid - en plicht - een eigen voorzitter aan te wijzen en welke overwegingen daarachter liggen. Die kennis is namelijk nog maar zeer beperkt beschikbaar.

\section{Literatuur}

BMC, Op weg naar de griffier van de toekomst, BMC Groep, Leusden: 2007.

Buylen, B., P.G. Castenmiller \& K. De Ceuninck, 'Controle op Nederlandse wijze in Vlaamse gemeenten. Pure science fiction of realistisch toekomstscenario?', Vlaams Tijdschrift voor Overheidsmanagement, 2014/3, p. 47-62.

Elzinga, D.J., 'Burgemeester is politieke functionaris geworden', Binnenlands Bestuur, 24 mei 2013.

Fraanje, M.J., Sturen in dienstbaarheid. Verkennend essay naar de rollen van de gemeenteraad bij de uitvoering van de nieuwe taken in het sociaal domein, Raadslid.nu, Den Haag: 2015.

Gilsing, R.J.H., H. Boutellier, T. Nederland, B. Noordhuizen \& E. Smits van Waesberghe, De gemeenteraad in een nieuwe rol. Over democratische legitimiteit in het sociale domein, Verwey-Jonker Instituut, Utrecht: 2015.

Karsten, N. \& S. van Zuydam, 'Hoeder van de raad' of 'functie zonder inhoud'? Een beschouwing op het vicevoorzitterschap van de gemeenteraad, Tilburg University, Tilburg: 2017.

Karsten, N., K. De Ceuninck \& H. Reynaert, 'Burgemeester (m/v) in de Lage Landen: Zelfde job? Zelfde rol? Zelfde vragen?', Res Publica, 2017/3, p. 307-330. 
Karsten, N., L. Schaap, F. Hendriks, S. van Zuydam \& G.J. Leenknegt, Majesteitelijk en magistratelijk. De Nederlandse burgemeester en de staat van het ambt, Tilburg University, Tilburg: 2014.

Korsten, A.F.A. \& H. Aardema, De vallende burgemeester. Een onderzoek naar factoren, omstandigheden, patronen en preventie- en interventiemogelijkheden, Ministerie van Binnenlandse Zaken en Koninkrijksrelaties, Den Haag: 2006.

Krouwel, A. \& B. Geurkink, 'Politieke fragmentatie in Nederlandse gemeenteraden', M.J.E.M. van Dam e.a. (eds.), De geleerde griffier. Jaarboek van griffiers 2016, Delft: 2016, p. 127-139.

Kruiter, A.J. \& S.L. de Lange, 'De toekomst van de gemeenteraad', Beleid en Maatschappij, 2014/1, p. 143-145.

Lunsing, J.R. \& M. Herweijer, 'Politieke fragmentatie in Nederlandse gemeenten', Bestuurswetenschappen, 2016/1, p. 5-16.

Mein, A., 'Uitbreiding bevoegdheden ter handhaving van de openbare orde en veiligheid. Een versterking of verzwakking van de positie van de burgemeester?', Tijdschrift voor Veiligheid, 2010/3, p. 34-44.

Ostaaijen, J.J.C. van, Hard naar het college, zacht naar de samenleving. Op zoek naar een nieuwe verbindende rol van de gemeenteraad, Tilburg University, Tilburg: 2016.

Ostaaijen, J.J.C. van \& P. Thijssen, 'Wat weten we eigenlijk van elkaar? Lokale politiek en lokale verkiezingen in Nederland en België', Res Publica, 2017/3, p. 246-253.

Peters, C.E., De controlerende raad, bijdrage aan de Dag voor de Raad, Delft: 17 maart 2017.

Raad van State, Jaarverslag 2016, Den Haag: 2017.

Rob, 15, 9 uur. De verbindende rol van het raadslid in een vitale democratie, Raad voor het openbaar bestuur, Den Haag: 2016a.

Rob, Begin bij het begin. Advies over de rol, positie en aanstellingswijze van burgemeesters, Raad voor het openbaar bestuur, Den Haag: 2016b.

Schulz, J.M. \& P.H.A. Frissen, Politieke fragmentatie. Balanceren tussen effectiviteit, legitimiteit en representativiteit, NSOB, Den Haag: 2017.

Stuurgroep Evaluatie Dualisering Gemeentebestuur, Aangelegd om in vrijheid samen te werken. Dualisering: bijsturing geboden, Den Haag: 2004.

Suykens, M., 'De rol van de gemeenteraadsvoorzitter: een versterking van de gemeenteraad', H. Reynaert, K. Steyvers \& T. Verhelst (eds.), De gemeente- en provincieraad. Meer dan mopperen en legitimeren, Brugge: 2010, p. 117-131.

Verbeek, M. \& M. Van Bouwel, 'Meer democratie dankzij aparte gemeenteraadsvoorzitter', Lokaal, 2012/14, p. 12-14.

Vlaamse Regering, Ontwerp van memorie van toelichting bij het ontwerp van Gemeentedecreet, Brussel: 2005.

VVSG, Opmerkingen bij het ontwerpdecreet lokaal bestuur, Vereniging van Vlaamse Steden en Gemeenten, Brussel: 2017.

Wolman, H. \& E. Page, 'Policy transfer among local governments. An information-theory approach', Governance, 2002/4, p. 477-501. 